\title{
The Care Economy as Alternative Economy
}

\author{
Sandra Sullivan-Dunbar \\ Loyola University Chicago, ssull1@luc.edu
}

Follow this and additional works at: https://ecommons.luc.edu/theology_facpubs

Part of the Religious Thought, Theology and Philosophy of Religion Commons

\section{Recommended Citation}

Sullivan-Dunbar, Sandra. The Care Economy as Alternative Economy. Working Alternatives: American and Catholic Experiments in Work and Economy, , : 21-44, 2020. Retrieved from Loyola eCommons, Theology: Faculty Publications and Other Works, http://dx.doi.org/10.5422/fordham/9780823288359.001.0001

This Book Chapter is brought to you for free and open access by the Faculty Publications and Other Works by Department at Loyola eCommons. It has been accepted for inclusion in Theology: Faculty Publications and Other Works by an authorized administrator of Loyola eCommons. For more information, please contact ecommons@luc.edu.

\section{(c) $(\ominus)$}

This work is licensed under a Creative Commons Attribution-Noncommercial-No Derivative Works 3.0 License. (c) Fordham University Press, 2020. 


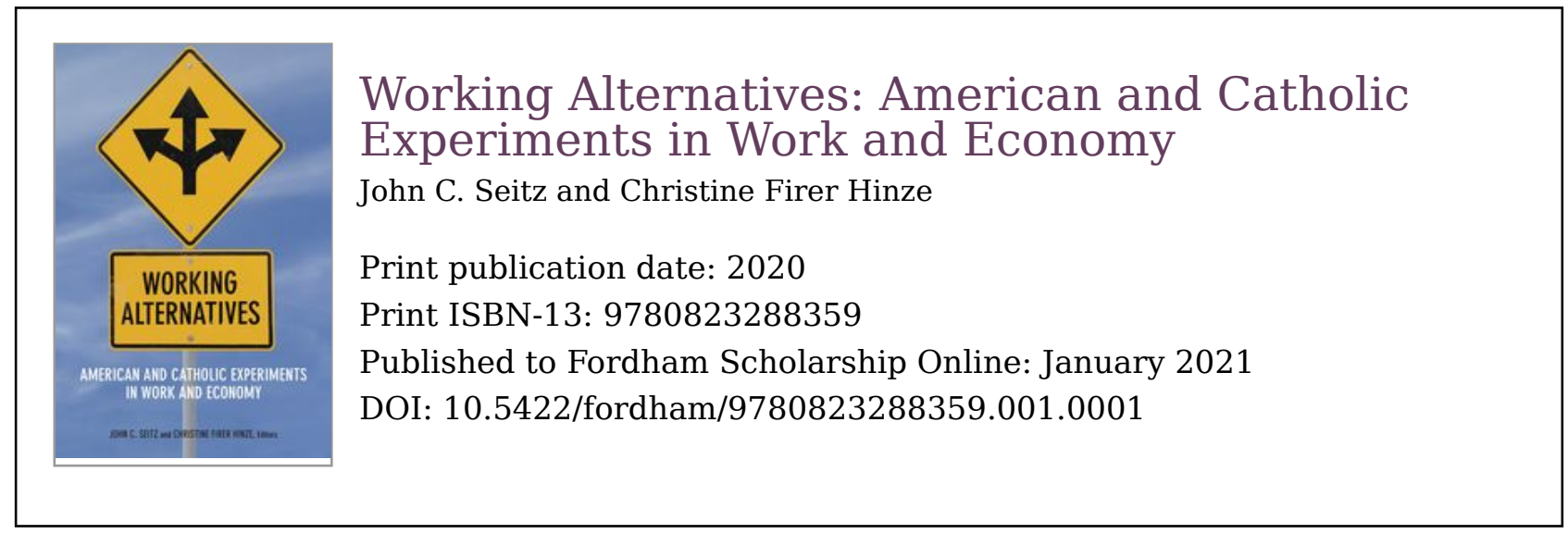

\section{The Care Economy as Alternative Economy}

Sandra Sullivan-Dunbar

DOI:10.5422/fordham/9780823288359.003.0002

\section{[-] Abstract and Keywords}

This essay explores the care economy, defined as activity oriented toward sustaining life and promoting basic well-being, whether that activity is paid or unpaid. The essay finds parallels between Pope Benedict XI's concerns about neoclassical economics as expressed in Caritas in Veritate and feminist scholarship addressing the care economy. Both Benedict and feminist economists challenge sharp binaries between the market and the state and affirm a spectrum of motives driving economic activity. Both Benedict and feminist economists critique an individualistic, voluntaristic anthropology of self-interest, and both understand true economic development to promote the holistic well-being of all persons. However, Benedict does not draw on scholarship about development and the care economy. Progress toward the vision of development outlined in $C V$ requires consideration of this economy and acceptance of a more complex and pluralist account of the social organization of caregiving than Benedict envisions.

Keywords: care economy, Caritas in Veritate, feminist economics, Pope Benedict XVI, unpaid labor

This volume seeks to examine experiments in "alternative economies" and the conceptions of the human person that undergird them. In my contribution here, I will focus on an enormous and pervasive alternative economy that has existed for longer than the market economy: the care economy. By care economy, I mean human activity that is oriented toward sustaining life and promoting basic well-being, whether that activity is paid or unpaid, and the material goods that are devoted toward this task, whether or not those goods are mediated through the market. In one sense, it is not appropriate to call the care economy an alternative economy; as I will argue, our contemporary conception of the economic must be broadened to incorporate care.

Nevertheless, the care economy can be seen as alternative because it has largely been written out of the discipline of economics and of everyday conceptions of economy. A volume exploring alternative economies cannot be complete without attention to this under-theorized economic activity. When we begin to think of the economy as incorporating care and other work oriented 
toward sustaining life, we find that many fundamental assumptions about human motives and the human good that underlie contemporary economic theory come into question.

In this essay I explore the care economy. I document its erasure during the development of classical and neoclassical economic theory. I track recent work by feminist economists and development theorists to reincorporate care into conceptions of the economic, taking account of the proportion of overall economic activity that care represents and the implications of care relations for our understandings of the human person and social relations. To think of care as economic is to disrupt the theorization of economic activity as motivated primarily and predictably by self-interest. Care work is very often unpaid, so establishing care giving as economic activity signifies that the economy is not coextensive with the (p.22) market. At the same time, a significant portion of care work is paid, which shows that market activity can incorporate relations involving other-regard and self-gift. Furthermore, paid and unpaid care are deeply interrelated with one another, often coexisting within the same caring practice. These facts have implications for our understanding of the economic as well as for social welfare policies and development policies.

Pope Benedict XVI's 2009 encyclical, Caritas in Veritate (CV), calls for a more integral understanding of development, and for a "further and deeper reflection on the meaning of the economy and its goals."1 One of my primary theses is that there exist suggestive parallels between many of Benedict's concerns in this encyclical, and concerns expressed by feminist economists addressing the care economy. These include challenges to sharp binaries between the market and the state and affirmation of a spectrum of motives driving economic activity. Benedict and feminist economists also share a critique of an anthropology that highlights autonomous choosers and ignores aspects of our existence that come to us as gift, as well as a concern for economic development that addresses the holistic well-being of all persons. These parallels, coming from what might be seen as very different perspectives, suggest that contemporary economic theory indeed holds a far too narrow understanding of economic activity. The parallels also suggest that some of Benedict's own concerns might be addressed via engagement with economists studying caring labor. However, Benedict does not draw on feminist economics at all, nor does he so much as mention the care economy. The practical impact of his ideas is seriously curtailed by this omission. Dialogue with scholarly work on the care economy would provide Catholic economic thinkers with additional, powerful tools to press the central concerns expressed by Benedict but would also challenge these thinkers to accept a more complex and pluralist account of the appropriate social organization of caregiving than Benedict appears to presume. This dialogue would help developers of the Catholic social tradition to embrace more embodied and material dimensions of "the astonishing experience of gift" that is a central theme of $C V$ and to articulate more clearly a role for (p.23) the state in supporting the care economy. ${ }^{2}$ This chapter begins that dialogue.

The first section of this essay will briefly trace the history of the exclusion of care from conceptions of economy during the evolution of classical and neoclassical economics, as well as of the sharp bifurcation of altruistic and self-interested motives within economic theory. The second section will turn to $C V$, pointing out some initial parallels between Benedict's central concerns in this encyclical and concerns raised by feminist economists in their treatments of the care economy. The third section will address efforts by economists and development theorists to reincorporate caregiving into economic analysis, including methods to measure the scope of the care economy, and will discuss the role of the state in supporting the care economy. The fourth section will address concerns about the "commodification" of care and attend to the 
complexities of motive in the care economy. Throughout, I will place Benedict into conversation with scholarship on the care economy, arguing that we can only make progress toward the vision of development outlined in $C V$ if we take into consideration the pervasive economy of care.

\section{How Care Was Excluded from Economics: A Brief History}

Caregiving was not always considered to be outside the scope of economics. Before the Industrial Revolution, the economy (or "oeconomy") was understood in terms of stewardship of resources to assure subsistence and well-being. Writing in 1769, Sir James Steuart connected economy in the household with political economy:

Oeconomy, in general, is the art of providing for all the wants of a family, with prudence and frugality. ... The object of it, in a private family, is ... to provide for the nourishment, the other wants, and the employment of every individual. ... What oeconomy is in a family, (p.24) political oeconomy is in a state ... The principle object of this science is to secure a certain fund of subsistence for all the inhabitants, to obviate every circumstance which may render it precarious; to provide every thing necessary for supplying the wants of the society, and to employ the inhabitants ... in such a manner as naturally to create the reciprocal relations and dependencies between them, so as to make their several interests lead them to supply one another with their reciprocal wants. ${ }^{3}$

Steuart's vision of "oeconomy" was embedded in a thoroughly hierarchical and patriarchal understanding of both family and government. Still, feminist economists have suggested that we recover this notion of economics as "provisioning," as an important ingredient alongside economics as the study of market behavior. ${ }^{4}$

How was this notion lost in the first place? Economic historians have traced the erasure of the domestic economy from the scope of the economic, beginning with the work of Adam Smith. Smith's Wealth of Nations was written in the earliest stages of the Industrial Revolution, as production increasingly moved outside of the household into small "manufactories." Interested in the economic growth that new production processes could generate, Smith distinguished productive from unproductive labor, defining the latter as labor aimed at capital accumulation, which would increase the productivity of future labor. ${ }^{5}$ Unproductive labor was valuable, but only in the sense of maintaining subsistence in the here and now: "A man grows rich by employing a multitude of manufacturers. He grows poor, by maintaining a multitude of menial servants." ${ }^{6}$ Smith did include "the acquired and useful abilities of all the inhabitants or members of the society" as a form of productive labor, resulting in "a capital (p.25) fixed and realized, as it were, in (the) person."7 This included the labor of teachers and masters of apprentices. He did not, however, include straightforward caring labor, such as child-rearing, within the scope of productive labor. ${ }^{8}$

Indeed, the analytic tools that Smith developed could not easily be applied to caregiving relations. Much caregiving activity is aimed precisely at subsistence, at the value of living well here and now within embodied limits. Caregiving is not an activity that lends itself to everincreasing productivity. Unlike Smith's pin factory workers, increasing production through the division of labor, caregivers must be generalists, engaging a wide and varied range of activities within their caregiving practice. Furthermore, care frequently involves deep attachment and attention to very particular needs and circumstances. Economists presume a certain degree of fungibility in the labor supply, allowing them to predict wages and labor mobility. But for many types of care, if caregivers are treated as fungible, the care recipient cannot thrive. Recognizing this, caregivers do not act according to predictable laws of self-interest in allocating their 
caregiving labor. And although care for children might be theorized as an investment in later productivity (and it is this, though this is certainly not all that it is), care for the elderly or for persons with severe disabilities is aimed at the present end of living well here and now, not at later productivity. ${ }^{9}$ Care escapes Smith's frame because it often involves a range of motives: care cannot be good care without some degree of other-regard, of placing the needs of the care recipient over one's own needs some of the time. Yet care can also be deeply rewarding, and caregivers must find ways to care for themselves in order to continue caring for others.

Nancy Folbre and Heidi Hartmann suggest Smith gave little attention to the domestic economy in part because complex motives undermine predictability. We can predict what fair but selfinterested persons will do within exchange relations with strangers. We cannot so easily predict the outcome of economic activity embedded in intensive relations (p.26) imbued with affection, self-interest, inequality, and power relations. ${ }^{10}$ Additionally, Smith could ignore the caregiving economy, because he assumed that care would occur: women were presumed to be naturally suited to it, and their love for care recipients was presumed sufficient and reliable motivation for such labor. In Smith's work, therefore, self-interest drove economic relations outside the home; affective relations and other-regard were located inside the home.

In the second half of the nineteenth century, as the industrial economy increasingly became a commercial economy, the discipline of economics evolved further toward an emphasis on market and exchange processes. The "marginalist school," what is today known as neoclassical economics, defined the value of commodities as the price at which supply meets demand. ${ }^{11}$ Economic activity that occurred outside the market- including unpaid labor-posed a problem here; without a price, how can the value be determined? Alfred Marshall, author of the classic Principles of Economics that was first published in 1890 and remained the standard introductory textbook for decades, asserted that "(t)he most valuable of all capital is that invested in human beings; and of that capital the most precious part is the result of the care and influence of the mother." 12 Still, he argued that "gratuitous" (unpaid) services should be "left to be accounted for separately." ${ }^{13}$ Marshall argued for the inclusion of salaries for domestic servants in calculations of social income, and noted the "inconsistency in omitting the heavy domestic work which is done by women and other members of the household, where no servants are kept." ${ }^{14}$ However, he did nothing to address this inconsistency. Marshall's followers quickly enshrined the exclusion of unpaid domestic labor from (p.27) economic calculations, and failed to pursue the separate accounting that Marshall suggested. ${ }^{15}$ Thus, nonmarket labor, production, and exchange simply disappeared from the subject matter of marginalist economics.

In addition, the marginalist school further sharpened the bifurcation of self-interest from otherregard, and the assignment of these motives to sharply separated public and private spheres. Outside the family, "preferences" were theorized as "inscrutable." In other words, we have no way of determining what and how much a particular person desires except by observing his choices in the marketplace; we cannot access another's internal experience ${ }^{16}$ However, within the family, preferences are "soluble" and family members hold a joint utility function. That is to say, family members are fully aware of the preferences of all other family members and desire things as a unit. ${ }^{17}$ The family is altruistic, noncompetitive, and family members know each other intimately. Thus, the family is the mirror opposite of the self-interested, competitive marketplace. In either case, there is no objective account of the goods to be sought through economic activity. Preferences, either observed through self-interested choices in the 
marketplace or perceived through an intimate altruistic concern, are the only indicators of appropriate economic purpose.

Benedict does not engage this history of economic thought in $C V$. However, we will see that his conception of economics incorporates many elements that were deliberately banished from the discipline during the course of this history.

\section{Caritas in Veritate}

Benedict XVI's 2009 encyclical is framed as a reaffirmation of and reflection on Pope Paul VI's 1967 encyclical, Populorum Progressio, and like his predecessor, Benedict focuses sharply on the perceived causes (p.28) and remedies of global poverty and inequality. Benedict offers a conception of caritas as necessary to the "integral human development" advocated by Paul VI. Integral human development addresses all aspects of the human person: material, social, and spiritual. For Benedict, caritas, or charity, is connected to an objective moral order (charity in truth) and must infuse all levels of politics, economy, and society. Furthermore, "authentic human development concerns the whole of the person in every single dimension," including the transcendent dimension of the person, the dimension that is destined for eternal life. ${ }^{18}$ Benedict describes integral human development as a vocation, which "involves a free assumption of responsibility in solidarity on the part of everyone."19

Benedict also takes aim at what he perceives as an exaggerated emphasis on autonomy: "Sometimes modern man is wrongly convinced that he is the sole author of himself, his life and society." ${ }^{20}$ To counter this false sense of autonomy, Benedict argues that we must be open to "the astonishing experience of gift." ${ }^{21}$ Benedict elucidates this experience in terms of nonmaterial realities: truth, hope conscience, caritas. $^{22}$ Without contesting these spiritual forms of gratuity, I suggest that he ought to attend to an embodied, material form of gratuity that is essential to human life, particularly in an encyclical on economics. This is the gratuitous experience of care, a care that we must receive to survive and grow into adulthood, and require in periods of disability, illness, or frailty. This care is profoundly material. It is care for embodied persons, and requires material goods to meet material needs. We must view the transcendental, spiritual dimension that Benedict highlights as existing in and through a material, everyday other-regard such as that called out by dependent care relations.

The development of classical and neoclassical economic theory deliberately excluded normative considerations to make economics appear more scientific; for example, neoclassical economics deliberately excludes any account of the goods to be sought through economic activity, other (p. 29) than the preferences expressed by autonomous choosers in the marketplace. ${ }^{23}$ In contrast, Benedict insists that economics is normative to its core. Benedict insists that the economy "needs to be directed towards the pursuit of the common good." ${ }^{24}$ Its primary purpose is holistic human wellbeing, where "holistic" includes, especially, a transcendent aspect. Economic activity that damages human persons and communities thereby subverts its own ends. ${ }^{25}$ Furthermore, in language that echoes Alfred Marshall's assertion that the most valuable capital is invested in human beings, Benedict declares that "the primary capital to be safeguarded and valued is man, the human person in his or her integrity." ${ }^{26}$ In its emphasis on well-being and on the development of human persons rather than just on products, Benedict's discussion here recalls the care economy, but he appears unaware of this parallel, and his emphasis on the spiritual aspects of well-being are not balanced by attention to the embodied needs attended to within care relations. 
Caritas in Veritate also engages the relationship between the state, the economy, and civil society. Initially, Benedict describes each of these sectors as driven by unique motives or "logics": the economy operates according to the logic of exchange; the state operates according to the logic of duty and compulsion. ${ }^{27}$ Having articulated these sharp distinctions, Benedict then declares "this exclusively binary model of market-plus-state" to be "corrosive of society." ${ }^{28}$ The "logic of gift" is most at home in civil society but must also infuse the economy and state. He advocates a plurality of forms of political authority and economic activity, arguing for a spirit of mutuality and solidarity from the most local level to the highest and most inclusive.

In the market economy, such an infusion can be expressed through "hybrid forms of commercial activity," or organizations that aim both at profit and at broader social goods. ${ }^{29}$ These organizations reflect a "wide (p.30) range of values," not simply self-interest. ${ }^{30}$ Benedict encourages the development of fiscal and juridical frameworks for the development of a range of such enterprises. ${ }^{31} \mathrm{He}$ asserts that "authentically human relationships of friendship, solidarity and reciprocity can also be conducted within economic activity, and not only outside it or 'after' it." 32 Of course, if we conceive of the economy as incorporating care, then economic activity that expresses a range of motives and values appears to be the norm, rather than the exception, and the neoclassical assumptions that Benedict is resisting are already in trouble.

The state too must be infused with a "principle of gratuitousness." 33 Benedict's first encyclical, Deus Caritas Est (2005), cast state-sponsored care as bureaucratic and impersonal, lacking the "look of love" that occurs through personal encounter. ${ }^{34}$ But $C V$ seems to show an evolution: here, Benedict asserts that the state must be a channel of charity, and that individuals must express their charity politically: "This is the institutional path-we might also call it the political path-of charity, no less excellent and effective than the kind of charity which encounters the neighbor directly, outside the institutional mediation of the polis." 35 At the same time, Benedict notes that the forces of globalization have weakened the sovereignty of the state, and suggests that the role and powers of "public authorities" must be "prudently reviewed and remodeled" in light of the forces of globalization. ${ }^{36}$

Interestingly, Benedict does not explicitly include the family in this discussion of social institutions. Though some scholars have suggested that the family should be considered as part of civil society, ${ }^{37}$ Benedict's discussion of civil society remains undeveloped in this document. Though earlier documents in Catholic social thought describe the family as the (p.31) "cell of society" and assign the family a social justice function, ${ }^{38}$ Benedict does not pick up these themes in $C V$. References to the family occur in two primary contexts. First, Benedict repeatedly references the human race as a family, ${ }^{39}$ and even titles one of his chapters as such. ${ }^{40}$ His point is that the globalization requires that we be concerned for the inclusion of all within the scope of integral human development, but he gives little attention to the local kinship networks that constitute family in the everyday sense of the term, and that serve as the concrete locus for material relations of giving and receiving, of care, and of subsistence. Rather, Benedict refers to the usual kinship-based family of parents and children primarily as the locus of sexuality and procreation, and the protector of sexual morality-the second primary context under which "family" is considered in $C V$.

Although Benedict's silence on the economic importance of unpaid care work is striking, it is perhaps not surprising. Official Catholic social documents assume that most care should be given in the home, and presume the primary financial support for families should come from a (male) breadwinner. Benedict's predecessor, John Paul II, affirmed women's access to public 
roles as long as this did not endanger their most central vocation, that of motherhood. Although John Paul II urged that "the work of women in the home be recognized and respected by all in its irreplaceable value," it is clear that he considers this work to be women's work, and that women and men have "different vocations." 41 Though John Paul II at one point suggests the state provide "grants to mothers devoting themselves exclusively to their families," 42 Benedict does not emphasize the need for state support for caregiving relations even in this (p.32) limited respect, infused as it is with assumptions about traditional gender roles. As we shall see, development theorists who attend to the care economy see state support for caregiving as essential to effective development policy.

In sum, we can see how Benedict seeks to introduce into our conception of the economy some elements that were quarantined during the development of the discipline of economics. These include a range of motives that may be expressed in the same economic practice, a sense of indebtedness and gratuity that precedes and limits our autonomy, and a normative conception of the aims of economics. He also addresses the role of the state, the market and civil society in development, and critiques impermeable divisions between them, but his discussion of the role of kinship and family in development is seriously underdeveloped. In the next section, we will see feminist work on the care economy aiming to reintegrate some of the same elements. But this feminist scholarship is more thorough, pluralistic, nuanced, and sophisticated than Benedict's generalities. In part, this is a function of the genre of the papal encyclical, which seeks a certain level of generality and avoids technical policy prescriptions. But I suspect that Benedict avoids scholarship on the care economy because even as it offers a path toward more successful development policy, it would challenge his gendered understandings of care and the family.

\section{Bringing Care Back into Economics: Recent Feminist Work}

As we have seen, care was excluded from increasingly specialized and "scientific" economic theory in part because it would have been more complex and difficult to predict caring behavior, as opposed to market behavior. Not surprisingly, then, the project of integrating unpaid care work back into the scope of the economic is challenging. Arguably, however, it is no more complex than other developments in economics that stretch the neoclassical model to address areas outside the market, such as the valuation of public goods like clean water or the cost of carbon emissions. In fact, there has been a great deal of work, particularly over the last two decades, to conceptualize care as a portion of the broader economy. ${ }^{43}$

(p.33) Even before the last two decades, some economists (even those teaching within the neoclassical fortress that is the University of Chicago) analyzed the domestic economy. In the mid-twentieth century, Hazel Kyrk focused her work on household consumption, and developed a concept of economic waste as the diversion of resources to "whims" before basic needs were met. ${ }^{44}$ Clearly, such an approach presupposes a normative account of the goods that economic activity should seek to further, a departure from the orthodox view. Kyrk's student Margaret Reid developed methods to measure the economic value of household production and unpaid domestic labor. ${ }^{45}$ More recently, Nancy Folbre is one prominent economist attending to the economic valuation of caregiving and domestic labor. ${ }^{46}$

Efforts to theorize the microeconomics of the household are complemented by work to incorporate unpaid domestic labor into macroeconomic analysis. A substantial body of scholarship has shown that a failure to attend to care, unpaid work, and women's work (distinct categories, but ones that overlap significantly), leads to counterproductive development policies. 
Given that Caritas in Veritate is focused primarily on development, it is striking that Benedict did not engage this work, much of which was available well before 2009.

In 1988, Marilyn Waring published an extensive critique of the United Nations's System of National Accounts (SNA), a system developed in 1953 to measure economic production. ${ }^{47}$ The SNA excluded unpaid domestic (p.34) labor from the "production boundary"-activity that would be included within gross domestic product calculations. Other feminist scholars elucidated similar themes. In an important 1992 article, Diane Elson laid out several ways in which male bias structures the macroeconomic analysis that has undergirded much development policy. This analysis presumes that human labor is unproduced-it basically ignores reproductive labor-and that human labor can be transferred quickly and without cost between activities, "in the way that a piece of land may be used for growing one crop one year and a different crop the next." 48 International financial organizations also emphasized the production of goods for trade over goods for consumption inside the country. This practice not only put developing countries at risk should international supply and demand change but also obscured the fact that production for consumption inside the country is largely subsistence consumption. ${ }^{49}$ In other words, the analytic frameworks assume that labor will simply be transferred from one activity to another; they do not account for the possibility that overall labor may increase (for example, to ensure continued survival while goods are being produced for export), and that much of the increased labor may be unpaid. In addition, most macroeconomic analysis did not account for the fact that gender roles may render men unwilling to take on labor that is culturally understood as "women's work." To the extent that this sort of work must increase in response to structural adjustment policies, women will often be the ones taking on additional labor. ${ }^{50}$

In response to work by Waring, Elson, and others, the 1993 version of the SNA was amended to suggest "satellite accounts" to measure non-market activities that were not initially included in the "production boundary," including unpaid domestic labor. ${ }^{51}$ Furthermore, the platform (p.35) for action of the 1995 United Nations Conference on Women in Beijing set forth, as one of its strategic objectives, a call for "developing methods ... for assessing the value, in quantitative terms, of unremunerated work that is outside national accounts, such as caring for dependents and preparing food." 52 The initial emphasis at Beijing was on recognition of the enormous amount of unpaid work in the economy, and the high proportion of such work done by women. This resulted in the development of time-use studies that were well-suited to the estimation of the overall proportion of work that was unpaid and the development of household sector satellite accounts to better estimate aggregate economic output. ${ }^{53}$ Early time-use studies generally did not separate out care work from other unpaid activities like subsistence farming.

Over the intervening two decades, more detailed methods of time-use data collection have been developed. These allow economists to discern, for example, the impact of structural adjustment policies on the amount of unpaid labor done by women, and can support advocacy for greater public support of certain services or infrastructure. For example, detailed time-use accounts might bring to light the significant amount of time spent collecting water or reveal the time cost of cooking less expensive foods, which generally require longer preparation. Time-use surveys can also help track the movement of care back and forth from the paid to the unpaid economy, as when, after the implementation of structural adjustment programs, cutbacks in public-sector health care spending results in increased unpaid care work in the home. Among other loci of research, (p.36) the United Nations Research Institute on Social Development conducted the Political and Social Economy of Care project between 2006 and 2009, compiling both 
quantitative and qualitative research on how care is provided by household, state, market, and community in a number of developed and less developed countries. ${ }^{54}$

There are complications associated with collecting time-use data on unpaid care, and researchers have used a variety of methods, each with their own strengths and weaknesses. ${ }^{55}$ But as Debbie Budlender notes, "There are ... also far more complications and heroic assumptions associated with the estimation of GDP than most who use this measure generally recognize." ${ }^{56}$ Furthermore, research attempting to measure the care economy, whether through time-use studies or other methods, has only begun to emerge in the last two to three decades; given the immensity and complexity of that economy, we should not yet expect fine-grained pictures of variations in care economies that emerge from cultural differences and varied levels of economic development. Despite the challenges and the variety of methods used to assign a monetary value to unpaid care, three consistent findings remain clear across studies: the care economy represents a very significant proportion of the overall economy; a large proportion of care is unpaid care (which, in turn, depresses the wages for paid care); and the majority of care, paid and unpaid, is performed by women, across the globe. ${ }^{57}$

(p.37) The International Monetary Fund (IMF) and the World Bank have based their lending policies on macroeconomic models that ignore unpaid care; consequently, they have imposed significant cutbacks in government funding for health, education, and public services as loan conditions. These services then are either not delivered at all, or are provided through private channels, primarily without pay and by women. Development scholars who attend to the care economy are virtually unanimous in their view that strong state support for care services is a prerequisite both to gender equality and to successful development policies. ${ }^{58}$ This need is dictated by the very nature of the care economy. Care is a public good; it is not subject to everincreasing productivity, and beyond a certain (very limited) point, pressures to make care more "productive" will dramatically reduce the quality of care. ${ }^{59}$

In the last few years, the World Bank and the IMF have shown signs of evolution in their approach to gender inequality, issuing policy recommendations, including better family benefits, accessible finance and property rights for women, tax benefits for low-wage earners, and increased public expenditures on education, infrastructure, and health. Recent reports have also discussed the division of domestic unpaid labor between women and men. ${ }^{60}$ But these emphases stand in tension with the still-dominant neoclassical assumption that productivity and growth are measured by earnings and that "economic participation" by women is equivalent to increased participation in paid labor. ${ }^{61}$ Although women's legal and practical access to paid employment is indeed important, this language obscures the fact that across the globe, women do more work (p.38) than men, when both paid and unpaid labor are taken into account. ${ }^{62}$ In the full sense of "economic" advocated in this chapter, women already demonstrate more economic participation than men; they simply get paid less for it, and paid for less of it. Furthermore, although policy papers may create gradual conceptual shifts among decision-makers at international financial institutions, this process is slow and, some would argue, easily co-opted by the dominant neoclassical paradigm; there is no direct link between such papers and the conditions of actual lending agreements.

In sum, there is now an extensive body of work on the extent and importance of the care economy, which even international financial institutions are now beginning to recognize. Benedict briefly criticizes IMF and World Bank policies: "budgetary policies, with cuts in social spending often made under pressure from international financial institutions, can leave citizens 
powerless in the face of old and new risks." ${ }^{\prime 63}$ However, he does not connect this critique to discussions of the care economy, and the increase in unpaid care that is consequent upon reduced state spending. Were he to do so, his advocacy of "integral human development" would be more compelling; he could add a powerful voice to those asking that unpaid care be factored into development policy.

As we have seen, Benedict is concerned to avoid a sharp binary between market and state. Here again, scholarship on the care economy could be helpful, as it moves well beyond the binary. ${ }^{64}$ Many who study (p.39) care regimes in various countries are beginning to use the term "care diamond" to reference four institutional sectors-state, market, households, and communitieseach of which are involved in the provision of care, in unique but overlapping ways. ${ }^{65}$ Although the primary motives operating in each sector of the care diamond may be distinctive-for example, affection and other-regard may motivate much care within the family, and the expectation of payment is an important incentive for care provided in the market-in fact varied motives pervade all four institutional loci for care provision. ${ }^{66}$ This points to an important parallel between care economics and Benedict's conception of economy: both are concerned to demonstrate (and encourage) a more complex account of motives within economic activity than that presumed in neoclassical economic theory.

\section{Fears of Commodification: Can We Mix Love and Money?}

The conceptual split between the market as the realm of self-interest and care as the realm of altruism has led many to worry that paid care represents the intrusion of an inappropriate motive into an activity that should be driven by affection and concern. Some care scholars openly worry about and debate the impact of the "commodification of care." ${ }^{\prime 67}$ Although this worry often seems to operate at the level of intuitive values, some scholars attempt an empirical argument that money taints altruistic love or care. An oft-cited study found that people who received payment for blood donations were more likely to lie about medical conditions and to pass on infections than people who donated their blood. ${ }^{68}$ Similarly, in some situations, monetary remuneration has been shown to (p.40) "crowd out" altruistic motivations for attending to the needs of others. ${ }^{69}$ Such studies have been used to argue for low salaries in caring occupations. ${ }^{70}$ However, as Nelson and Folbre point out, studies of the relationship between remuneration and motivation have shown different impact based on the framing of the remuneration. If it is perceived as controlling the agency of the person helping another, it "crowds out" altruism; if it is perceived as recognizing the intrinsic altruistic motivation of the person, it "crowds in" altruism-it increases other-regarding behavior. ${ }^{71}$

Benedict does not openly worry about these questions because he never discusses paid care. And yet Benedict is eager to inject the spirit of gift into the business arena, traditionally seen as the realm of self-interest. Why, then, does he not notice and embrace the coexistence of monetary payment and other-regard within relations of care? I suspect this has much to do with assumptions about women's natural caring role and about the private home as the most appropriate location for care. When we think of caregiving as economic activity, some of which is mediated by the money economy, we reveal the integration of self-interest and other-regard within the practice of care. We also reveal the ways in which caregiving, even within a nuclear family, is connected to the public and economic realms. These complexities and connections stand in tension with the gender essentialism espoused by Benedict's predecessor, John Paul II, and embedded within much of the Catholic social tradition. John Paul II asserted that women possess a "feminine genius," rendering them particularly attuned to the needs of others and particularly suited to self-gift. ${ }^{72}$ Women and men have different vocations, and while women 
should have access to public roles, these roles should not impede a woman's most (p.41) central role, the maternal role. ${ }^{73}$ The gender binary is mapped onto a public/private binary, and discussion of monetary compensation of care would seem to threaten this binary as well as the self-gift that is presumed to be the particular genius of women.

Even if there is reason to worry about the commodification of care, it is better to worry out loud and debate its benefits and dangers, than to remain silent about such concerns. Some care is already (and should be) commodified, and honest engagement with the care economy demands that we examine and grapple with the benefits and dangers of this commodification. In developed economies, most of us meet our care obligations through a combination of paid and unpaid care. Care receivers sometimes prefer their care to be delivered through a market contract, rather than through preexisting relationships, for a wide range of reasons. ${ }^{74}$ Furthermore, we should not assume that accepting pay for care represents the dilution or poisoning of other-regard with self-interested motives. Caregiver salaries are not generally spent to fulfill the insatiable desire for more presumed by neoclassical economic theory, but for the necessities of a decent life: "our very human need for basic food and shelter is at the base of our work 'for money.'" 75 If we think of paid care as serving both the human needs of the care recipient (through care) and the human needs of the caregiver (through monetary reimbursement), then paying for care is not a matter of competing ends, but a way to meet the ends of both parties in the relationship. Paid caregiving relations can involve genuine otherregard, affection, and even love: these motives are not mutually exclusive. This will be unsurprising to those of us who employ paid caregivers for our own family members, and empirical studies have demonstrated their coexistence. For example, a recent (p.42) study concluded, through both in-depth interviews and four hundred hours of participant-observation, that childcare workers in United Kingdom nurseries find their work rewarding, develop powerful attachments to the children in their care, and perform emotional labor to set boundaries to these attachments. $^{76}$

Thus, paid care is not intrinsically problematic: paid care serves many good purposes. The most pressing problem associated with paid care is not the tainting of care, but the exploitation of caregivers. Such exploitation has, in the United States, frequently been facilitated by the assumption that the "higher" aspects of care are the nonmaterial aspects: the affective or "spiritual" aspects of care. These aspects of care are most likely to be seen as needing "protection" from the taint of remuneration: you can't buy love. And these aspects of care are frequently conceptually separated from the material and often "dirty" aspects of care: washing bodies, feeding, dressing, drawing blood, cleaning wounds. In historical practice in the United States, the "dirty" aspects have frequently been assigned to women marginalized by race, class, and nationality. ${ }^{77}$ Christine Firer Hinze argues that such a division of reproductive labor reflects gnostic tendencies, a purity-based attempt to escape our embodiment. She calls for a retrieval of the incarnational elements of Christian faith to combat the deep social inequalities that are reinforced through a purity-based division of work with dirt and bodies. ${ }^{78}$

(p.43) This discussion of attitudes toward paid care has drawn primarily on examples from the United States and other highly developed Western countries. We cannot extrapolate such attitudes to other contexts (indeed, caregivers in less-developed countries may not have the luxury of distinguishing affective concern from the material, embodied aspects of care in a division of caring labor). However, development policies that have increased the burden of unpaid labor on women have been conceived and imposed largely by persons from the United States and other wealthy countries, who may share in the unexamined assumption that 
caregiving is properly motivated by love and not money, that love should be infinitely elastic, that true care requires no material support, and is even tainted by it. But the material prerequisites of care, both the goods that meet human needs and the embodied labor of care, are not infinitely elastic; they require support through the state, the economy, and the community. Too often, this material support has been eliminated through austerity policies imposed by international lending organizations. Thus, attitudes that drive injustice to caregivers in the United States are also implicated in development policies that impose suffering in poor countries.

Benedict wants to reintegrate self-interest with other-regard through a range of commercial forms. My discussion here suggests that a significant portion of the economy already displays the range of motives that Benedict encourages within the business sector. This combination of motives is not intrinsically problematic; and who can better speak to the possibility of multiple ends and motives than the professional childcare worker, teacher, or home health aide? These multiple motives can coexist within an overall practice that meets both the needs of the recipient for care and the needs of the caregiver for economic sustenance. Yet this range of motives is often obscured, and this obfuscation reinforces structures of privilege and exploitation, and underwrites a counterproductive approach to development. We must view interest in material return for caregiving labor not as a failure of caring, but as appropriate and necessary motives for this embodied labor. Efforts to humanize the economy must attend to a spectrum of options both for business enterprise and for caregiving arrangements, and must allow for close, critical (p.44) assessment of economic arrangements all along this spectrum, in both the care economy and the market economy. Benedict does not evidence the same comfort with a plurality of caregiving arrangements, as he does with a plurality of commercial enterprise forms. And although Benedict argues for a spirit of caritas to infuse a mutually supportive relationship between state and economy, he does not fully address the intersections of all aspects of the "care diamond"-state, market, household, and communities-which are necessary to support a fully incarnational "integral human development," a development that provides material support for caregiving labor.

\section{Conclusion}

The domestic economy, including caregiving, was extracted from conceptions of the "economic" during the development of classical and neoclassical economic theory. Current efforts to reintegrate care into economic theory and measurement are crucial for gender justice and for effective development policies and practices. In addition, reintegrating care into economic theory requires alterations to the anthropology underlying economics. Care is an embodied, incarnational practice. As such, the care economy must involve a range of motives-care is intrinsically focused on the needs of others, but caregivers are needy beings as well, and must and should attend to their own needs.

Benedict suggests that we need an openness to the transcendent for charity and the "spirit of gift" to pervade our market economy, but he does not turn to the economy of embodied relationships of dependency and caregiving as a site where such charity is already pervasive. Thereby, he devalues the embodied aspects of caritas, the work of dealing directly with frail and often messy bodies. A truly incarnational approach to development would also recognize and support the embodied care that necessarily pervades human life. Future Catholic social thought on development would do well to attend to the insights of feminist scholars of the care economy. 


\section{Notes:}

(1.) Pope Benedict XVI, Caritas in Veritate 32, Encyclical Letter, Vatican website, June 29, 2009, http://w2.vatican.va/content/benedict-xvi/en/encyclicals/documents/hf_benxvi_enc_20090629_caritas-in-veritate.html (italics in original).

(2.) Within the tradition of papal writings on economics, I focus on Benedict because he addresses neoclassical assumptions in original ways that suggest points of intersection with writings on the care economy-for example, in his call for juridical frameworks to facilitate hybrid forms of commercial activity, and in his affirmation of a range of legitimate motives within market activity.

(3.) Sir James Steuart, An inquiry into the principles of political oeconomy, Edinburgh: Oliver \& Boyd for Scottish Economic Society, 1966 [1770]).

(4.) Julie A. Nelson, "The Study of Choice or the Study of Provisioning? Gender and the Definition of Economics," in Beyond Economic Man: Feminist Theory and Economics, ed. Marianne A. Ferber and Julie A. Nelson (Chicago: University of Chicago Press, 1993), 23-36.

(5.) Adam Smith, An Inquiry into the Nature and Causes of the Wealth of Nations, vol. 1, ed. R. H. Campbell and A. S. Skinner (Oxford: Oxford University Press, 1976; reprint Indianapolis: Liberty Fund, 1981), 330.

(6.) Ibid.

(7.) Ibid., 282.

(8.) Michelle A. Pujol, Feminism and Anti-Feminism in Early Economic Thought, (Alder-shot, England: Edward Elgar Press, 1992), 18.

(9.) Susan Donath, "The Other Economy: Suggestions for a Distinctively Feminist Economics," Feminist Economics 6:1 (2000): 115-23.

(10.) Nancy Folbre and Heidi Hartmann, "The Rhetoric of Self-Interest: Ideology and Gender in Economic Theory," in The Consequences of Economic Rhetoric, ed. Arjo Klamer, Donald N. McCloskey, and Robert M. Solow (Cambridge: Cambridge University Press, 1988), 198, n.2.

(11.) William Stanley Jevons, The Theory of Political Economy, 2nd ed., ed. R. D. Collinson Black (Baltimore: Penguin, 1970); Carl Menger, Principles of Economics (New York: Free Press, 1950); Leon Walras, Elements of Pure Economics (Homewood, IL: Irwin, 1954).

(12.) Alfred Marshall, Principles of Economics: An Introductory Volume, 8th ed. (New York: Macmillan, 1948 [1890]), 564.

(13.) Ibid., 524.

(14.) Ibid., 80.

(15.) Pujol, Feminism and Anti-Feminism, 134.

(16.) For a historical account of debates among economists over the ability to discern others' preferences or utility functions, see Drucilla Barker, "Economists, Social Reformers, and 
Prophets: a Feminist Critique of Economic Efficiency," Feminist Economics 1, no. 3 (1995), 2639.

(17.) Paul Samuelson, “Social Indifference Curves," Quarterly Journal of Economics 70, no. 1 (1956).

(18.) Benedict XVI, CV 11 (italics in original).

(19.) Ibid.

(20.) Ibid., 34.

(21.) Ibid.

(22.) Ibid.

(23.) For more on this, see Sandra Sullivan-Dunbar Human Dependency and Christian Ethics (New York: Cambridge University Press, 2017), 56-69.

(24.) Benedict, $C V 36$.

(25.) Ibid., 32.

(26.) Ibid., 25.

(27.) Ibid., 39.

(28.) Ibid.

(29.) Ibid., 36.

(30.) Ibid., 41

(31.) Ibid., 46.

(32.) Ibid., 36.

(33.) Ibid.

(34.) Ibid.,18.

(35.) Ibid., 7.

(36.) Ibid., 24.

(37.) See, for example, Lisa Sowle Cahill, Family: A Christian Social Perspective (Minneapolis: Fortress Press, 2000).

(38.) Pope John Paul II, Familiaris Consortio (http://w2.vatican.va/content/john-paul-ii/en/ apost_exhortations/documents/hf_jp-ii_exh_19811122_familiaris-consortio.html), 42-44.

(39.) Benedict, $C V, 8,13,33,50,73$.

(40.) Ibid., chapter 5, "The Cooperation of the Human Family" (CV 43-67). 
(41.) John Paul II, Familiaris Consortio, 23.

(42.) John Paul II, Laborem Exercens, 19, Vatican website, September 14, 1981, http:// w2.vatican.va/content/john-paul-ii/en/encyclicals/documents/hf_jp-ii_enc_14091981_laboremexercens.html. This suggestion, to my knowledge, was not repeated by John Paul II in later writings.

(43.) Riane Eisler argues for a broader conception of economics-one that incorporates both care and natural resources, in her The Real Wealth of Nations (San Francisco: Berret-Koehler Publishers, 2007), in a way that is accessible to a popular audience.

(44.) Susan van Velzen, "Hazel Kyrk and the Ethics of Consumption," in Toward a Feminist Philosophy of Economics, ed. Drucilla K. Barker and Edith Kuiper (London: Routledge, 2003), 40.

(45.) Margaret G. Reid, Economics of Household Production (New York: John Wiley, 1934), 11, cited in Yun-Ae Yi, "Margaret G. Reid: Life and Achievements," Feminist Economics 2, no. 3 (1996), 21-22. The work of Kyrk and Reid has, unfortunately, been largely overshadowed by that of another Chicago economist, Gary Becker, the so-called Father of the "New Home Economics." See Gary Becker, A Treatise on the Family (Cambridge, MA: Harvard University Press, 1991). While Becker challenged some neoclassical assumptions, the neoclassical approach remains dominant in his work and generates absurd, gendered, and hierarchical accounts of the family. For these arguments, see Sullivan-Dunbar Human Dependency, 69-74.

(46.) Nancy Folbre, Valuing Children: Rethinking the Economics of the Family (Cambridge, MA: Harvard University Press, 2008).

(47.) Marilyn Waring, If Women Counted: A New Feminist Economics (San Francisco: Harper \& Row Publishers, 1988).

(48.) Diane Elson, "Male Bias in Macroeconomics," in Women and Adjustment Policies in the Third World, ed. H. Afshar and C. Dennis (New York: St. Martin's Press, 1992), 166.

(49.) Ibid., 167.

(50.) Ibid., 168.

(51.) Other satellite accounts address other important values that are not captured by the pricing mechanism, such as natural resources. In addition to this system of satellite accounts, other systems have been developed more recently to measure economic productivity and wellbeing in a more holistic sense. The genuine progress index (GPI), developed in 1995, measures a wide range of goods and, in addition, counts certain "bads" as negatives. For example, cleanup from the damage from Hurricane Katrina reflected an increase in gross domestic product (GDP), but the hurricane represented an enormous negative in terms of overall human well-being (http://www.gpiatlantic.org/gpi.htm). The Organization for Economic Co-operation and Development's Better Life Index (BLI, oecdbetterlifeindex.org) and the United Nation's Human Development Index (HDI, hdr.undp.org) both measure well-being in terms of qualitative categories such as housing, education, and nutrition, rather than measuring economic progress by GPD alone. These latter systems measure outcomes rather than labor, productivity, and exchange, but an economic system that recognizes, supports, and rewards caregiving activity is likely to produce better outcomes as measured by the GPI, BLI, or HDI. 
(52.) UN Fourth World Conference on Women 1995: Strategic objective H.3, point (f), published in Feminist Economics 2, no. 3 (1996), 125-28.

(53.) Valeria Esquivel, "Sixteen Years After Beijing: What Are the New Policy Agendas for TimeUse Data Collection?," Feminist Economics 17, no. 4 (October 2011), 217.

(54.) For research conducted under the auspices of this project, see http://www.unrisd.org/ research/gd/care.

(55.) See Esquivel, "Sixteen Years"; Debbie Budlender, "What Do Time Use Studies Tell Us About Unpaid Care Work? Evidence from Seven Countries," in Time Use Studies and Unpaid Care Work, ed. Debbie Budlender (New York: Routledge/UNRISD Research in Gender and Development, 2010), 2; Debbie Budlender, A Critical Review of Selected Time Use Surveys (Geneva: UNRISD, Gender and Development Programme Paper Number 2, June 2007).

(56.) Budlender, “Time Use Studies," 41.

(57.) In addition to Budlender's work, see Miranda Veerle, "Cooking, Caring, and Volunteering: Unpaid Work Around the World," OECD Social, Employment, and Migration Working Papers No. 116 (Paris: OECD Publishing, 2011), http://dx.doi.org/10.1787/5kghr-jm8s142-en; Mignon Duffy, Randy Albelda, and Clare Hammonds, "Counting Care Work: The Empirical and Policy Applications of Care Theory," Social Problems 60, no. 2 (2013), 145-67.

(58.) Kate McInturff and Brittany Lambert, Making Women Count: The Unequal Economics of Women's Work (Oxfam Canada and Canadian Center for Policy Alternatives, March 2016).

(59.) Duffy, Albelda, and Hammonds, “Counting Care Work,” 150.

(60.) World Development Report 2012: Gender Equality and Development (Washington, DC: The International Bank for Reconstruction and Development/The World Bank, 2011); Christian Gonzales, Sonali Jain-Chandra, Kalpana Kochhar, Monique Newiak, and Tlek Zeinullayev, "Catalyst for Change: Empowering Women and Tackling Income Inequality," (International Monetary Fund: October, 2015).

(61.) Shahra Razavi, "World Development Report 2012: Gender Equality and Development: A Commentary," Development and Change 43, no. 1 (2012), 425; Lourdes Beneria, "The World Bank and Gender Inequality," Global Social Policy 12, no. 2 (August 2012), 175-78.

(62.) Although this is most pronounced in the least developed countries, it remains true in the United States. According to the 2015 American Time Use Survey, while men worked more hours per day in paid employment (4.18 hours to women's 2.92), total work time (paid and unpaid) was higher for women. When combining time devoted to household activities (housework, food preparation, lawn and garden care), direct physical care to other persons, purchasing goods and services, and paid employment, adult women spent an average of 6.94 hours per day working, while men work an average of 6.68 hours per day. See Bureau of Labor Statistics, "American Time Use Survey: 2015 Results" (June 24, 2016), available at https://www.bls.gov/news.release/ archives/atus_06242016.pdf. Calculations are made from data on the chart in Table 1, page 9: "Time spent in primary activities and percentage of the civilian population engaging in each activity, averages per day by sex, 2015 annual averages."

(63.) Benedict, $C V 25$. 
(64.) Ibid., 41.

(65.) Shahra Ravazi, The Political and Social Economy of Care in a Development Context UN RISD Gender and Development Programme Paper 3, (June 2007), ix; Parvati Raghuram, "Global Care, Local Configurations-Challenges to Conceptualizations of Care," Global Networks 12, no. 2 (2012), 155-74.

(66.) Raghuram, “Global Care,” 166.

(67.) Virginia Held, "Care and the Extension of Markets," Hypatia 17, no. 2 (2002), 19-33; Susan Himmelweit, "The Discovery of 'Unpaid Work': the Social Consequences of the Expansion of 'Work'," Feminist Economics 1:2 (1995), 1-19.

(68.) Richard M. Titmuss, The Gift Relationship: From Human Blood to Social Policy (New York: Vintage Books, 1971).

(69.) Bruno S. Frey, "Institutions and Morale: the Crowding-Out Effect," in Economics, Values, and Organization, ed. Avner Ben-Ner and Louis Putterman, (Cambridge: Cambridge University Press, 1998), 437-60.

(70.) Anthony Heyes, "The Economics of Vocation or 'Why is a Badly Paid Nurse a Good Nurse?'” Journal of Health Economics 24 (May 2005), 561-69.

(71.) Julie A. Nelson and Nancy Folbre, "Why a Well-Paid Nurse is a Better Nurse," Nursing Economics 24, no. 3 (May-June 2006), 127-30.

(72.) John Paul II, Mulieris Dignitatem, apostolic letter, Vatican website, August 15, 1988, http:// w2.vatican.va/content/john-paul-ii/en/apost_letters/1988/documents/hf_jpii_apl_19880815_mulieris-dignitatem.html, par. 30.

(73.) John Paul II, Familiaris Consortio, apostolic exhortation, Vatican website, November 22, 1981, http://w2.vatican.va/content/john-paul-ii/en/apost_exhortations/documents/hf_jpii_exh_19811122_familiaris-consortio.html, par. 23.

(74.) Rutger Claasen, "The Commodification of Care," Hypatia 26, no.1 (Winter 2011), 50-51; Hazel Qureshi, "Boundaries Between Formal and Informal Care-Giving Work," in Gender and Caring: Work and Welfare in Britain and Scandinavia, ed. Claire Ungerson (London: Harvester Wheatsheaf, 1990), 68.

(75.) Julie A. Nelson, “Of Markets and Martyrs: Is it OK to Pay Well for Care?," Feminist Economics 5 no. 3 (1999), 48.

(76.) Kate Boyer, Suzanne Reimer, and Lauren Irvine, "The Nursery Workplace, Emotional Labour and Contested Understandings of Commoditized Childcare in the Contemporary UK," Social \& Cultural Geography 14, no. 5 (2013), 517-40.

(77.) For studies of this phenomenon in the United States, see, for example, Evelyn Nakano Glenn, "From Servitude to Service Work: Historical Continuities in the Racial Divide of Paid Reproductive Labor," Signs 18, no. 1 (Autumn 1992), 1-43; Evelyn Nakano Glenn, Forced to Care: Coercion and Caregiving in America (Cambridge, MA: Harvard University Press, 2010); 
Dorothy E. Roberts, "Spiritual and Menial Housework," Yale Journal of Law and Feminism 9 (1997), 51-80.

(78.) Christine Firer Hinze, "Dirt and Economic Inequality: A Christian-Ethical Peek Under the Rug," Annual of the Society of Christian Ethics 21 (2001), 45-62. There is a parallel between these disparate attitudes to bodily caring labor and the disparate attitudes toward housekeeping pointed out by Kirsten Swinth in her contribution to this volume. In the battle for the inclusion of domestic labor under the Fair Labor Standards Act, middle-class feminists painted a picture of housework as tedious and dirty, and remuneration as compensation for tolerating such work. Domestic laborers themselves, who were often women of color, painted a picture of domestic work as a dignified and highly skilled profession, deserving of respect and wages that reflected professional expertise. 